\begin{tabular}{|c|l|}
\hline Title & $\begin{array}{l}\text { Preparation of highly dispersed Pt nanoparticles supported on zeolite templated carbon and catalytic application in } \\
\text { hydrogenation reaction }\end{array}$ \\
\hline Author(s) & $\begin{array}{l}\text { Jiang, Chuanxia; Hara, Kenji; Namba, Kotaro; Kobay ashi, Hirokazu; Ittisanronnachai, Somlak; Nishihara, Hirotomo; } \\
\text { Kyotani, Takashi; Fukuoka, A tsushi }\end{array}$ \\
\hline Citation & $\begin{array}{l}\text { Chemistry letters, 43(11), 1794.1796 } \\
\text { https://doi.org/10.1246/140699 }\end{array}$ \\
\hline Issue Date & 201411-05 \\
\hline Doc URL & http://hdl.handle.net/2115/57991 \\
\hline Type & article(author version) \\
\hline File Information & ChemLett_43_1794.pdf \\
\hline
\end{tabular}

Instructions for use 


\title{
Preparation of Highly Dispersed Pt Nanoparticles Supported on Zeolite-templated Carbon and Catalytic Application in Hydrogenation Reaction
}

\author{
Chuanxia Jiang, ${ }^{1,2}$ Kenji Hara, ${ }^{1}$ Kotaro Namba ${ }^{1,2}$ Hirokazu Kobayashi, ${ }^{1}$ Somlak Ittisanronnachai, ${ }^{3}$ Hirotomo Nishihara, ${ }^{3}$ \\ Takashi Kyotani ${ }^{3}$ and Atsushi Fukuoka*1 \\ ${ }^{1}$ Catalysis Research Center, Hokkaido University, Sapporo 001-0021 \\ ${ }^{2}$ Graduate School of Chemical Sciences and Engineering, Hokkaido University, Sapporo 060-8628 \\ ${ }^{3}$ Institute of Multidisciplinary Research for Advanced Materials, Tohoku University, Sendai 980-8577 \\ (Received <Month><Date>, <Year $>$; CL-<No>; E-mail: < fukuoka@cat.hokudai.ac.jp >)
}

Zeolite-templated carbon (ZTC) was utilized to prepare Pt nanoparticles as a support by using a simple impregnation method. The choice of a cationic Pt precursor led to the formation of highly and uniformly dispersed Pt nanoparticles on ZTC, which afforded a high conversion in catalytic hydrogenation of phenylacetylene.

In heterogeneous metal-catalyzed reaction, support materials play a key role in modifying catalytic activity and selectivity. Various metal nanoparticles have been prepared on numbers of metal oxides and carbons for a wide variety of catalytic application. Novel catalytic performance can be expected with a catalyst prepared on a new type of support material. Zeolite-templated carbon $(\text { ZTC })^{1}$ is a potentially promising support, because ZTC is a carbon replica obtained from a zeolite as a template, giving ordered three-dimensional micropores consisting of nano-sized graphene units. Although ZTC has been extensively studied as attractive materials for storage of hydrogen, ${ }^{2,3}$ electrochemical capacitors ${ }^{3}$ and lithium-ion batteries, ${ }^{3}$ its application in catalysis has been limited to the studies related with fuel cell. ${ }^{4}$ In addition, the metal nanoparticles incorporated in zeolite for fuel cell applications were prepared using Pt-incorporated zeolite. We thus envisioned further utilization of ZTC as a catalyst support by using a simple impregnation method. Herein we report the preparation of Pt nanoparticles on ZTC and their catalytic performance in hydrogenation of phenylacetylene.

Many inorganic and organic materials such as $\mathrm{SiO}_{2},{ }^{5} \gamma$ $\mathrm{Al}_{2} \mathrm{O}_{3},{ }^{6,8}$ pumice, ${ }^{7}$ zeolites, ${ }^{8}$ polymers, ${ }^{9}$ organic matrices, ${ }^{10}$ clays, ${ }^{11}$ mesostructured silica ${ }^{8,12}$ and $\mathrm{TiO}_{2}{ }^{13}$ have been already employed as supports for $\mathrm{Pt}, \mathrm{Pd}, \mathrm{Ni}$ and $\mathrm{Cu}$ catalysts in the hydrogenation of phenylacetylene. As recent examples of supported metal catalysts on carbon materials, $\mathrm{Pd}, \mathrm{Pt}, \mathrm{Ru}$ and $\mathrm{Pt}-\mathrm{Ru}$ on carbon nanotube were used for this reaction, ${ }^{14}$ whereas metal catalysts supported on ZTC have not been applied. ZTC was obtained by the reported method using zeolite $\mathrm{Y}$ as a template. ${ }^{1 \mathrm{~d}}$ The Pt catalyst supported on ZTC (Pt/ZTC) was prepared by a typical wet impregnation method. ZTC $(0.2 \mathrm{~g})$ was mixed with an aqueous solution $(50 \mathrm{~mL})$ of diamminedinitrito-platinum(II) $\left(\mathrm{Pt}\left(\mathrm{NH}_{3}\right)_{2}\left(\mathrm{NO}_{2}\right)_{2}\right)$ with a $\mathrm{Pt}$ loading of $2 \mathrm{wt} \%$. The mixture was stirred for $18 \mathrm{~h}$, evaporated to dryness and dried under vacuum for overnight. The resulting solid was reduced in $\mathrm{H}_{2}$ flow at $400{ }^{\circ} \mathrm{C}$ for $2 \mathrm{~h}$. For comparison, commercially available carbon materials such as Ketjen Black EC-600JD (KB) and Norit SX ultra (denoted as AC) were used as supports to prepare $\mathrm{Pt} / \mathrm{KB}$ and
Pt/AC, respectively. As another $\mathrm{Pt}$ precursor, hydrochloroplatinic acid $\left(\mathrm{H}_{2} \mathrm{PtCl}_{6} \cdot 6 \mathrm{H}_{2} \mathrm{O}\right)$ was used to prepare a Pt catalyst on ZTC (Pt/ZTC-Cl). The four Pt catalysts used in this study are summarized in Table 1.

Table 1. Preparation of Pt catalysts and their particle sizes.

\begin{tabular}{cccc}
\hline \multirow{2}{*}{ Pt catalysts } & \multirow{2}{*}{ Pt Precursor } & \multicolumn{2}{c}{ Pt particle diameter $(\mathrm{nm})$} \\
\cline { 3 - 4 } & & $\mathrm{XRD}$ & $\mathrm{TEM}$ \\
\hline $\mathrm{Pt} / \mathrm{ZTC}$ & $\mathrm{Pt}\left(\mathrm{NH}_{3}\right)_{2}\left(\mathrm{NO}_{2}\right)_{2}$ & 1.7 & $2.2 \pm 0.8$ \\
$\mathrm{Pt} / \mathrm{KB}$ & $\mathrm{Pt}\left(\mathrm{NH}_{3}\right)_{2}\left(\mathrm{NO}_{2}\right)_{2}$ & 2.5 & $3.5 \pm 1.2$ \\
$\mathrm{Pt} / \mathrm{AC}$ & $\mathrm{Pt}\left(\mathrm{NH}_{3}\right)_{2}\left(\mathrm{NO}_{2}\right)_{2}$ & 4.4 & $4.4 \pm 1.1$ \\
$\mathrm{Pt} / \mathrm{ZTC}-\mathrm{Cl}$ & $\mathrm{H}_{2} \mathrm{PtCl}_{6} \cdot 6 \mathrm{H}_{2} \mathrm{O}$ & 17 & $15 \pm 11$ \\
\hline
\end{tabular}

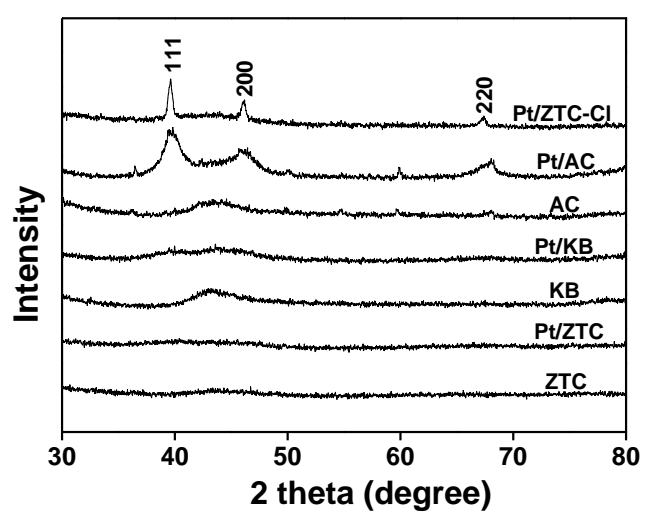

Figure 1. XRD patterns of carbon supports and supported $\mathrm{Pt}$ catalysts.

Figure 1 shows XRD patterns of the Pt catalysts and the carbon supports. No obvious Pt peaks were obtained for $\mathrm{Pt} / \mathrm{ZTC}$ and $\mathrm{Pt} / \mathrm{KB}$, giving weak and broad peaks at $40^{\circ}$. In contrast, three intense peaks were found with $\mathrm{Pt} / \mathrm{AC}$ and $\mathrm{Pt} / \mathrm{ZTC}-\mathrm{Cl}$ at 40,46 and $67^{\circ}$, which were assigned to (111), (200) and (220) reflections of face-centered cubic (fcc) Pt crystalline (JCPDS card, No. 04-0802), indicating the formation of large Pt nanoparticles. The Pt particle sizes of $\mathrm{Pt} / \mathrm{ZTC}, \mathrm{Pt} / \mathrm{KB}, \mathrm{Pt} / \mathrm{AC}$ and $\mathrm{Pt} / \mathrm{ZTC}-\mathrm{Cl}$ were estimated by the Scherrer equation with the (111) peaks to be 1.7, 2.5, 4.4 and $17 \mathrm{~nm}$, respectively (Table 1$)$.

In the TEM observation (Figure 2), the Pt particles on $\mathrm{Pt} / \mathrm{ZTC}$ were highly and uniformly dispersed on ZTC with a mean diameter of $2.2 \pm 0.8 \mathrm{~nm}$ based on 100 particles in random regions (Figure 2a). Larger Pt particles were observed in $\mathrm{Pt} / \mathrm{KB}$ and $\mathrm{Pt} / \mathrm{AC}$ with mean sizes of $3.5 \pm 1.2 \mathrm{~nm}$ and $4.4 \pm$ 
$1.1 \mathrm{~nm}$, respectively, as shown in Figure $2 \mathrm{~b}$ and c. In contrast, Pt/ZTC-Cl catalyst had a relatively larger size and broader distribution with $15 \pm 11 \mathrm{~nm}$ (Figure $2 \mathrm{~d}$ ). The Pt particle sizes analyzed by TEM were in good accordance with the results estimated by XRD (Table 1).

(a)
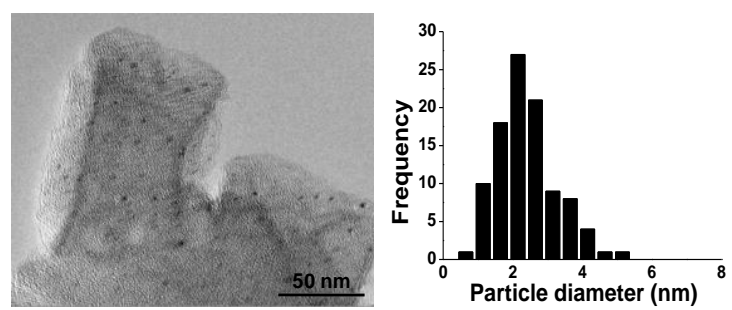

(b)
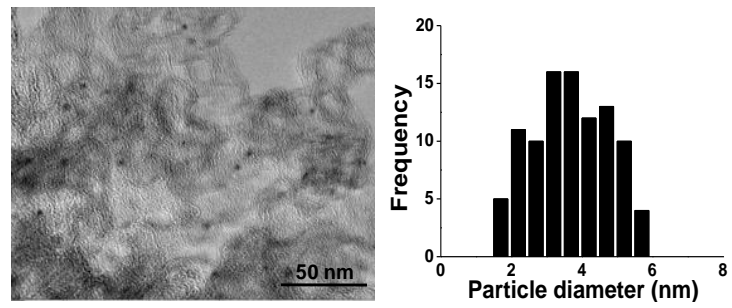

(c)
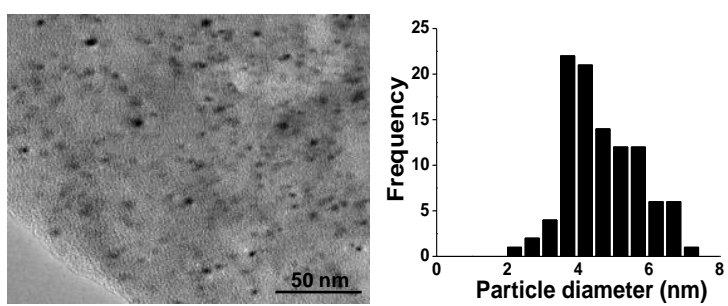

(d)
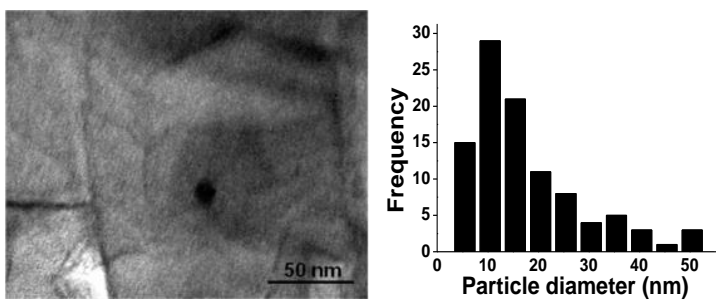

Figure 2. TEM images (left) and particle size distributions (right) of the (a) Pt/ZTC, (b) Pt/KB, (c) Pt/AC and (d) Pt/ZTC-Cl.

The uniformly dispersed smaller Pt particles observed in Pt/ZTC can be attributed to extremely high specific surface area of ZTC (ca. $4000 \mathrm{~m}^{2} \mathrm{~g}^{-1}$ ) compared to KB (ca. $800 \mathrm{~m}^{2} \mathrm{~g}^{-1}$ ) and $\mathrm{AC}$ (ca. $1200 \mathrm{~m}^{2} \mathrm{~g}^{-1}$ ). In addition, the high dispersion of $\mathrm{Pt}$ particles might be due to the presence of higher amount of surface functional groups on ZTC surface. ZTC has an uniquely high oxygen content $(9 \mathrm{wt} \%)$ and proposed oxygen functional groups are mainly ether groups together with minor functionalities such as phenol and acid anhydride. ${ }^{1 d}$ The cationic Pt precursor to prepare $\mathrm{Pt} / \mathrm{ZTC}, \mathrm{Pt}\left(\mathrm{NH}_{3}\right)_{2}{ }^{2+}$, possibly has a strong attractive interaction with such oxygencontaining functional groups on ZTC. In contrast, the anionic Pt precursor, $\mathrm{PtCl}_{6}{ }^{2-}$, can have a repulsive interaction with the surface functional groups ${ }^{15}$ on ZTC, which may enhance the aggregation of the Pt nanoparticles in Pt/ZTC-Cl.

Hydrogenation of phenylacetylene was carried out with $0.50 \mathrm{~mL}$ of phenylacetylene, $5.0 \mathrm{mg}$ of the catalyst and 4.5 $\mathrm{mL}$ of ethanol in a $50 \mathrm{~mL}$ autoclave under controlled $\mathrm{H}_{2}$ pressures and temperatures. The molar ratio of
phenylacetylene/Pt(bulk) was 8900. The products were analyzed by a Shimadzu GC-14B gas chromatograph using an FID detector with a capillary column (HR-1, $0.25 \mathrm{~mm} \times 50$ $\mathrm{m})$. A known amount of $n$-dodecane was added to the reaction mixture as an internal standard.

Figure 3 shows the conversion and selectivity for styrene by the Pt catalysts under the conditions of $0.40 \mathrm{MPa} \mathrm{H}_{2}$ at $50{ }^{\circ} \mathrm{C}$. Pt/ZTC catalyst afforded $63 \%$ conversion in $60 \mathrm{~min}$, which was apparently the best among the tested catalysts. $\mathrm{Pt} / \mathrm{KB}$ and $\mathrm{Pt} / \mathrm{AC}$ gave conversions of 53 and $25 \%$, respectively. Pt/ZTC-Cl resulted only in $3 \%$ conversion. The striking difference in conversion among the tested catalysts can be attributed to the difference in Pt particle size. The high dispersion of Pt nanoparticles on ZTC probably afforded the high conversion due to the more available Pt surface area for the reaction. This attribution can be supported by the fact that the conversions increase in almost direct proportion to the $\mathrm{Pt}$ surface areas estimated from the Pt particle diameters (Table $1)$.

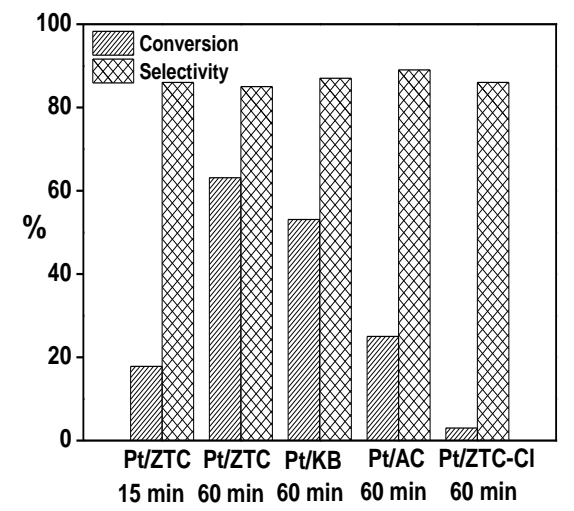

Figure 3. Hydrogenation of phenylacetylene over the different $\mathrm{Pt}$ catalysts supported on carbon. Reaction conditions: $0.4 \mathrm{MPa} \mathrm{H}_{2}$, $50{ }^{\circ} \mathrm{C}$

$\mathrm{Pt} / \mathrm{ZTC}$ catalyst was further utilized to investigate the influence of $\mathrm{H}_{2}$ pressure (Figure 4) and reaction temperature (Figure 5) on hydrogenation of phenylacetylene. As shown in Figure 4, the higher $\mathrm{H}_{2}$ pressure afforded the higher conversion of phenylacetylene, but the selectivity to styrene dramatically dropped under $0.70 \mathrm{MPa} \mathrm{H}_{2}$. Figure 5 indicates that elevated reaction temperature increases the phenylacetylene conversion while the styrene selectivity gradually decreases. The optimized conditions are $0.4-0.5$ $\mathrm{MPa}$ and $60-80{ }^{\circ} \mathrm{C}$, giving $75-78 \%$ yields of styrene in $60 \mathrm{~min}$.

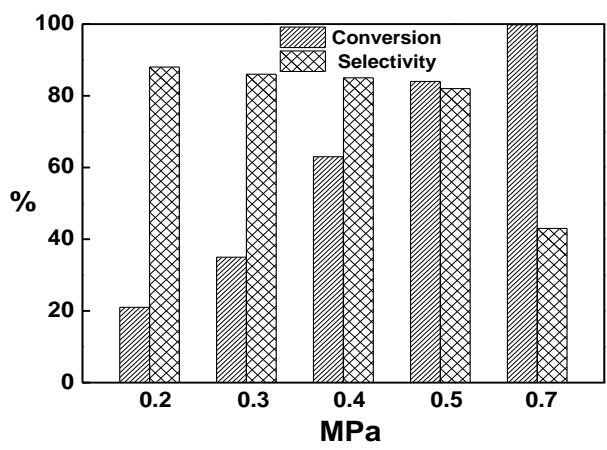


Figure 4. $\mathrm{H}_{2}$ pressure effect on hydrogenation of phenylacetylene over the Pt/ZTC catalyst. Reaction conditions: 0.2-0.7 $\mathrm{MPa} \mathrm{H}_{2}$, $50{ }^{\circ} \mathrm{C}, 60 \mathrm{~min}$

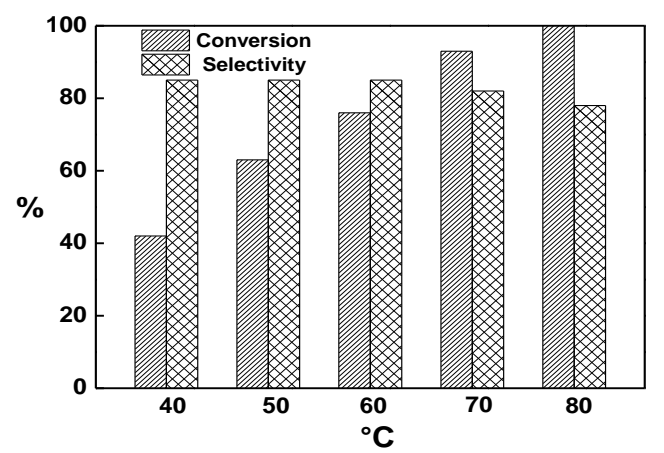

Figure 5. Reaction temperature effect on hydrogenation of phenylacetylene over the Pt/ZTC catalyst. Reaction conditions: 0.4 $\mathrm{MPa} \mathrm{H}_{2}, 40-80{ }^{\circ} \mathrm{C}, 60 \mathrm{~min}$

In order to confirm the durability of the Pt nanoparticles supported on ZTC, recycle use of Pt/ZTC for the catalytic reaction was conducted. As shown in Figure 6, the similar catalytic performance was obtained for three successive recycle runs. The heterogeneity of the catalyst was confirmed by observation of no further conversion after removing the catalyst from the reaction mixture. In addition, the TEM observation of $\mathrm{Pt} / \mathrm{ZTC}$ after the catalytic hydrogenation reaction showed almost no change in the narrow $\mathrm{Pt}$ particle size distribution $(2.2 \pm 0.8 \mathrm{~nm})$, which suggests the stability of the Pt nanoparticles on supported on ZTC during the reaction conditions.

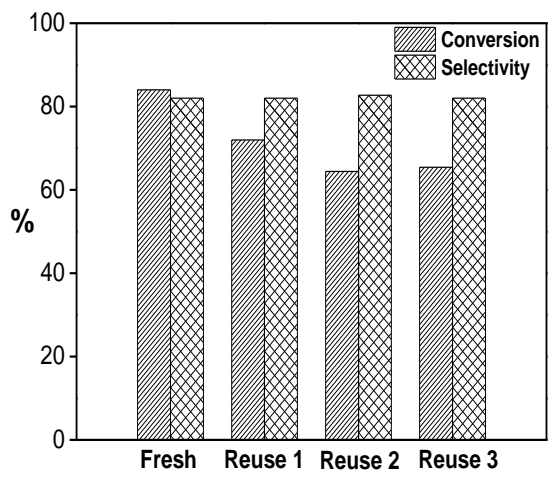

Figure 6. Recycle use of Pt/ZTC for hydrogenation of phenylacetylene. Reaction conditions: $0.4 \mathrm{MPa} \mathrm{H}_{2}, 50{ }^{\circ} \mathrm{C}, 60 \mathrm{~min}$

Although the selectivity to styrene with Pt/ZTC were not extremely high $(85-90 \%)$ even in a shortened reaction time (15 min) leading to a lower conversion (Figure 3), high conversions were obtained with a relatively low catalyst amount compared to a recently reported catalyst with $\mathrm{Pt}$ nanoparticles of $1.8 \mathrm{~nm}$ size (average size by TEM) supported on surface-oxidized carbon nanotube. ${ }^{14 c}$ The remaining byproduct was only ethylbenzene with the all $\mathrm{Pt}$ catalysts examined in this study.

In summary, Pt catalysts supported on zeolite-templated carbon (ZTC) were prepared by using a simple impregnation method and applied to hydrogenation of phenylacetylene. The utilization of ZTC as a catalyst support with a cationic $\mathrm{Pt}$ precursor gave highly and uniformly dispersed $\mathrm{Pt}$ nanoparticles and led to the highest conversion in catalytic hydrogenation of phenylacetylene among the Pt catalysts prepared in this study.

\section{Acknowledgement}

This research was supported by the Cooperative Research Program of Catalysis Research Center, Hokkaido University (Grant \#10A0001).

\section{References and Notes}

1 a) T. Cordero, P. A. Thrower, L. R. Radovic, Carbon 1992, 30, 365. b) P. Enzel, T. Bein, Chem. Mater. 1992, 4, 819. c) T. Kyotani, T. Nagai, S. Inoue, A. Tomita, Chem. Mater. 1997, 9, 609. d) H. Nishihara, Q.-H. Yang, P.-X. Hou, M. Unno, S. Yamauchi, R. Saito, J. I. Paredes, A. Martínez-Alonso, J. M. D. Tascón, Y. Sato, M. Terauchi, T. Kyotani, Carbon 2009, 47, 1220.

2 a) Z Yang, Y Xia, X. Sun, R. Mokaya, J. Phys. Chem. B 2006, 110, 18424. b) Z. Yang, Y. Xia, R. Mokaya, J. Am. Chem. Soc. 2007, 129, 1673. c) C. Guan, K. Wang, C. Yang, X. S. Zhao, Microporous Mesoporous Mater. 2009, 118, 503. d) H. Wang, Q. Gao, J. Hu, Z. Chen, Carbon 2009, 47, 2259. e) H. Nishihara, P.-X. Hou, L.-X. Li, M. Ito, M. Uchiyama, T. Kaburagi, A. Ikura, J. Katamura, T. Kawarada, K. Mizuuchi, T. Kyotani, J. Phys. Chem. C 2009, 113, 3189. f) N. Alam, R. Mokaya, Energy Environ. Sci. 2010, 3, 1773. g) Y. Xia, R. Mokaya, D. M. Grant, G. S. Walker, Carbon 2011, 49, 844. h) N. P. Stadie, J. J. Vajo, R. W. Cumberland, A. A. Wilson, C. C. Ahn, B. Fultz, Langmuir 2012, $28,10057$.

3 H. Nishihara, T. Kyotani, Adv. Mater. 2012, 24, 4473.

4 a) E. N. Coker, W. A. Steen, J. T. Miller, A. J. Kropf and J. E. Miller, Microporous Mesoporous Mater. 2007, 101, 440. b) E. N. Coker, W. A. Steen, J. T. Miller, A. J. Kropf, J. E. Miller, J. Mater. Chem. 2007, 17, 3330.

5 a) J. Panpranot, K. Phandinthong, T. Sirikajorn, M. Arai, P. Praserthdam, J. Mol. Catal. 2007, 261, 29. b) S. S. Mahmoud, I. M. Arafa, O. I. Sheikha, Asia J. Chem. 2000, 12, 1047.

6 G. Del Angel, J. L. Benitez, React. Kinet. Catal. Lett. 1993, 51, 547.

7 a) L. Guczi, Z. Schay, G. Stefler, L. F. Liotta, G. Deganello, A. M. Venezia, J. Catal. 1999, 182, 456. b) D. Duca, L. F. Liotta, G. Deganello, J. Catal. 1995, 154, 69.

8 S. Domínguez-Domínguez, Á. Berenguer-Murcia, Á. LinaresSolano, D. Cazorla-Amorós, J. Catal. 2008, 257, 87.

9 M. Terasawa, H. Yamamoto, K. Kaneda, T. Imanaka, S. Teranishi, J. Catal. 1979, 57, 315 .

10 F. Arena, G. Cum, R. Gallo, A. Parmaliana, J. Mol. Catal. A 1996, $110,235$.

11 a) Á. Mastalir, Z. Király, J. Catal. 2003, 220, 372. b) Á. Mastalir, Z. Király, F. Berger, Appl. Catal. A 2004, 269, 161.

12 a) A. Papp, Á. Molnár, Á. Mastalir, Appl. Catal. A 2005, 289, 256. b) N. Marín-Astorga, G. Pecchi, T. J. Pinnavaia, G. Alvez-Manoli, P. Reyes, J. Mol. Catal. A 2006, 247, 145.

13 P. Weerachawanasak, P. Praserthdam, M. Arai, J. Panpranot, J. Mol. Catal. A 2007, 279, 133.

14 a) S. Domínguez-Domínguez, Á. Berenguer-Murcia, B. K. Pradhan, Á. Linares-Solano, D. Cazorla-Amorós, J. Phys. Chem. C 2008, 112, 3827. b) E. V. Starodubtseva, M. G. Vinogradov, O. V. Turova, N. A. Bumagin, E. G. Rakov, V. I. Sokolov, Catal. Commun. 2009, 10, 1441. c) C. Li, Z. F. Shao, M. Pang, C. T. Williams, C. Liang, Catal. Today 2012, 186, 69. d) C. Li, Z. Shao, M. Pang, C. T. Williams, X. Zhang, C. Liang, Ind. Eng. Chem. Res. 2012, 51, 4934.

15 M. C. Román-Martínez, D. Cazorla-Amorós, A. Linares-Solano, C. Salinas-Martínez de Lecea, H. Yamashita, M. Anpo, Carbon 1995, 33,3 . 
NOTE The diagram is acceptable in a colored form. Publication of the colored G. A. is free of charge.

For publication, electronic data of the colored G.A. should be submitted. Preferred data format is EPS, PS, CDX, PPT, and TIFF. If the data of your G.A. is "bit-mapped image" data (not "vector data"), note that its print-resolution should be 300 dpi.

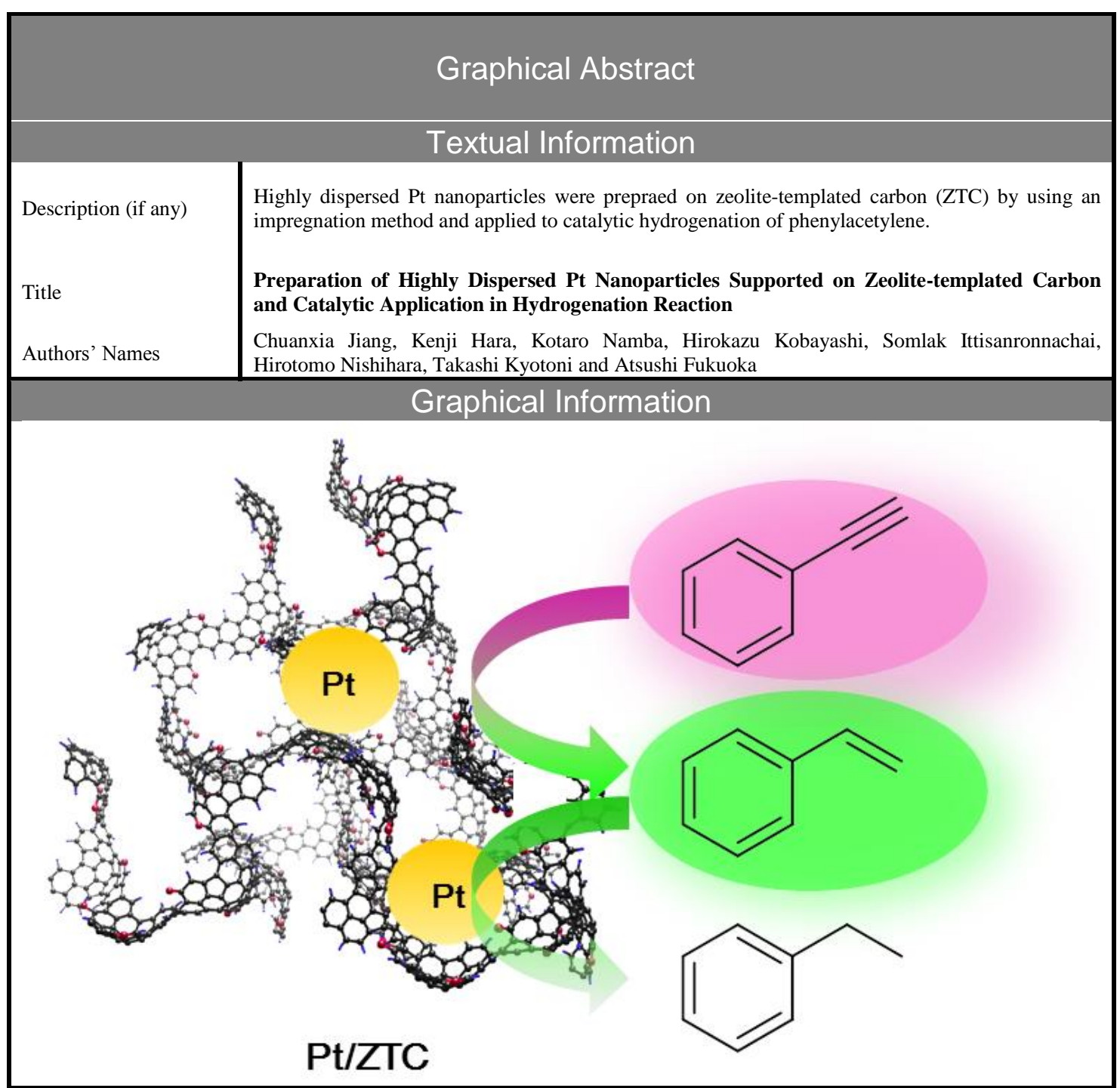

